\title{
Supplementation Effect of Purslane Seeds on Wheat Flour and Using it to Make Some Baked Products
}

\author{
Naglaa M. Shanshan, Dina H.EL Bushuty \\ Home Economics Dept., Fac. of Specific Education, Damietta Univ., Egypt.
}

\begin{abstract}
The present study aimed to studying the effects of supplemented wheat flour (extraction of $72 \%$ ) with purslane seeds powder and the possibility of using it to make some baked products . For this purpose, three types of baked products (batun salih, croissants, pizza) were prepared by adding three levels of purslane seeds powder $6 \%, 10 \%$ and $14 \%$ replacement with studying sensory properties for these products. The changes in the chemical composition and rheological properties of wheat flour were studied. Total of 21 male albino rats were divided into three equal groups (7 rats): control group C, group PS1 $(6 \%$ purslane seeds powder), PS2 (10\% purslane seeds powder). At the end of the experimental period (6 weeks) serum lipid profile (TC, TG, HDL-c, LDL-c), liver enzymes (AST, ALT, ALP), kidney functions (urea and creatinine) and blood glucose were examined. Histopathology of the heart, liver and kidney was also examined. Results showed that supplemented wheat flour with purslane seeds powder resulted significant increase $(\mathrm{P}<0.05)$ in protein, fat, ash and fiber, and significant decrease $(\mathrm{P}<0.05)$ in carbohydrate and energy. The results of the sensory tests showed not acceptance of supplemented baked products (batun salih, croissants, pizza) at 14\% purslane seeds powder, as well as croissants with $10 \%$ purslane seeds powder was not accepted while batun salih and pizza with $6 \%$ and $10 \%$ purslane seeds powder were accepted. The results of the farinograph and extensograph tests showed an increase in water absorption, dough stability, proportional number and maximum height, and decrease in arrival time, dough development time, resistance to extension, extensibility, and energy. For the results of biological assessment the results showed decrease in the weight gain, urea ,creatinine and blood glucose, significant increase $(\mathrm{P}<0.05)$ in HDL-c, and significant decrease $(\mathrm{P}<0.05)$ in TC, TG, LDL-c, AST, ALT and ALP compared to control. The results of histopathological examination showed that there were no bad effects of the purslane seeds powder on the liver, kidney and heart. The current study recommends supplementation wheat flour (extraction of $72 \%$ ) when making baked products with purslane seeds powder, for nutritional and health benefit of it, with more studies being necessary to determine the optimal levels of consumption in terms of sensory and rheological.
\end{abstract}

Key words: medical herbs, sensory properties, rheological properties , chemical composition, lipid profile, liver functions, kidney functions, blood glucose. 


\section{Introduction}

Medicinal Plants have a wide important role in the elemination on effects that caused by exposure to enviromental contaminants (Seif et al., 2019).Purslane (Portulaca oleracea L.) is an annual green herb slightly acidic, spinach-like taste and has succulent leaves, fleshy stem, yellow or white small flowers and small black seeds (Hussien and Salem, 2016 \& Rahimi et al.,2019). It is mentioned in Egyptian texts and it is a nutritious vegetable used for human consumption ( Dkhil $\boldsymbol{e l}$ al.,2011). In Arabic and Egypt the purslane is called 'Rejlah' to the family "Portulacaceae" (Abdalla, 2010 \& El Gindy, 2017). In Egypt About 935 tons of Rejlah are produced (Hussien and Salem, 2016).Rejlah is a widespread medicinal plant that is used not only as an edible plant, but also as a traditional medicine for alleviating a wide spectrum of diseases and it is generally known as a "longevity food" because its reputation as a "natural antibiotic" (Guo et al.,2016 \& Chugh et al., 2019).In China, purslane is used as a diuretic, antiseptic, febrifuge, antispasmodic , vermifuge and it is used for the treatment of viral hepatitis and in diabetes. It has a wide range of pharmacological effects, such as antibacterial ,antioxidative, hypolipidemic, anti-aging, anti-inflammatory, analgesic, and wound healing activities (Ghahramani et al.,2016). In this context, Purslane is use for treatment of burns, headache, and diseases related to the intestine, liver, stomach, cough, shortness of breath, arthritis, osteoporosis, anti-ulcerogenic and purgative (Uddin et al.,2014 \& Chugh et al., 2019).Purslane is listed in the World Health Organization as one of the most used medicinal plants. It has been described as a "power food" of future because of its anti-oxidant properties and its high nutritive. Rejlah, has high content of protein, ash and fiber (Hussien and Salem, 2016). Also, it contains vitamin C, carotene, vitamin $\mathrm{E}$ and $\mathrm{B}$ complex vitamins like riboflavin, , thiamin, niacin, and pyridoxine. It supplies highest dietary minerals such as potassium, magnesium, calcium, phosphorus, and iron (Uddin et al.,2014 \& Safaeian et al., 2018).Purslane is rich sources of antioxidants, vitamin $\mathrm{A}$, and $\mathrm{E}$, beta-carotene and essential amino acids (Sari and Sariçoban, 2016). Researchs indicate that the purslane contains many compounds, including alkaloids, omega-3 fatty acids, coumarins, flavonoids, cardiac glycosides, polysaccharides, anthraquinone glycosides and containing ß-sitosterol (Kamel et al.,2017).Rejlah is one of the most important medicinal plants and which is a good source of biologically active compounds including omega-3 fatty acids , $\beta$-carotene, ascorbic acid, amino acids, $\alpha$ tocopherols, glutathione, and flavonoids compounds. Many studies have demonstrated the beneficial effects of these compounds on metabolic profiles of persons with type 2 diabetes (Esmaillzadeh et al., 2015).Purslane is a commonly found species and a medicinal food for human consumption 
(Martins et al.,2016). Rejlah is a well-known plant for its antioxidant properties. Some studies have shown health benefits of rejlah in clinical conditions such as diabetic nephropathy, nephrotoxicity and hepatotoxicity (Askaripour et al.,2016).Rejlah is one of the richest green plant sources of omega-3 fatty acids. It has lower the cholesterol and triglyceride levels, and raise the beneficial high density lipoprotein. On the other hand, the ability of omega-3 fatty acids to decrease the thickness of the blood may be advantageous in the treatment of vascular diseases , Omega-3 fatty acids belong to a group of polyunsaturated fatty acids essential for human growth, development, maintenance of the immune, and prevention of numerous cardiovascular diseases(Uddin et al.,2014). The aim of the present study was to evaluate chemical composition, rheological and sensory properties of some baked products (batun salih, croissants, pizza) that produced from supplement wheat flour with purslane seeds powder also studying weight gain, lipid profile, liver and kidney functions, and blood glucose in the rats as well as histopathological examination for liver, kidney and heart .

\section{Materials and Methods}

\section{Materials:}

-Wheat flour ( $72 \%$ extraction), Purslane (Portulaca oleracea L.) seeds , sugar, margarine, oil, milk, tomatoes, olives, capsicum, roumi cheese, yeast, cumin and food salt were obtained from the local market, Damietta Governorate, Egypt.

-Twenty-one male albino rats (Sprague Dawley strain) weighing 160.00 $\pm 5 \mathrm{~g}$ were obtained from Helwan Farm.

-Vitamins, minerals, cellulose , choline chloride, casein, corn oil, corn starch, all chemicals and diagnostic kits were purchased from El-Gomhoria Co., Cairo, Egypt.

\section{Methods:}

\section{Preparing of purslane seeds powder:}

Purslane seeds were cleaned by hand to remove foreign materials, then were crushed in household mill, then was sifted. 


\section{Preparing of batun salih, croissants and pizza:}

Batun salih, croissants and pizza were prepared according to Saba, (1995), with substitution the wheat flour with purslane seeds powder at levels 6,10 and $14 \%$, respectively.

\section{Chemical analyses:}

Wheat flour ( extraction $72 \%$ ) that supplemented with purslane seeds powder was analyzed for its protein, fat, ash and fiber according to the A.O.A.C (2000), carbohydrate contents are calculated by difference. Total caloric content was determined according to Lawrence, (1965) .

\section{Rheological properties:}

The farinograph and extinsograph tests were done in National Research Center, Dokki, Giza, Egypt , carried out according to the method of A.A.C.C.(1995) .

\section{Sensory properties:}

Sensory properties for batun salih, croissants, pizza were evaluated by 30 subjects from Damietta Governorate, Egypt (15 males +15 females) aged between 25: 40 years. The evaluation was carried out according to the method of A.A.C.C.(2002) with some modification.

\section{Experimental animals:}

Twenty-one male albino rats (Sprague Dawley strain) weighing $160.00 \pm$ $5 \mathrm{~g}$ were fed on basal diet for one week according to Reeves et al., (1993), Then were divided into three equal groups ( 7 rats): control group C, group PS1 (6\% purslane seeds powder), PS2 (10\% purslane seeds powder).

\section{Blood sampling:}

At the end of experimental period ( 6 weeks), rats were fasted over night before sacrificing .Blood was collected and centrifuged .Serum was separated for analysis .Serum was carefully aspirate ,transferred into clean cuvet tubes, and stored frozen at $-20{ }^{\circ} \mathrm{C}$ until analysis. Body weight gain percent (BWG \% ) was calculated according to chapman et al.,(1959).

\section{Biochemical analysis:}

Serum total cholesterol (TC) were determined according to Allen, (1974).Triglycerides (TG) was done according to Fassati and Prencipe, 
(1982).High density lipoprotein-cholesterol (HDL-c) was determined according to Lopez, ( 1977 ), whereas low density lipoprotein-cholesterol (LDL-c) were determined according to Friedewable et al.,( 1972).

Determination of aspartate aminotransferase (AST) and alanine aminotransferase (ALT) were determined according to Reitman and Frankel,(1957). Serum alkaline phosphates (ALP) was carried out according to Belfield and Goldberg, (1971).Urea was determined according to Pattn and Crouch, (1977), the determination of creatinine was determined according to Henry, (1974), whereas glucose was determined according to Trinder, (1959).

\section{Histopathological examination:}

At the end of experimental period (6 weeks), rats were dissected heart, liver and kidney were excised from each rat. Representative samples were collected from each organ per rat and fixed in $10 \%$ formalin for histopathological examination. Fixed specimens were processed routinely until embedding in paraffin wax. Paraffin sections of 5 microns thickness were cut and picked up on glass slides, dried, deparafinized, rehydrated with graded alcohol, washed and stained with $\mathrm{H} \& \mathrm{E}$ according Bancroft and Gamble, (2007).

\section{Statistical Analysis :}

Statistical analyses were performed by using computer of statistical package for social science (SPSS version 11.0). The results are presented as means \pm SD. One way analysis of variance (ANOVA) was used to test the differences between groups (SPSS, 1999).

\section{Results and Discussion}

\section{Sensory evaluation of baked products with purslane seeds powder:}

Effect of treatments on sensory evaluation ( aroma, taste, color and overall acceptability) of batun salih, croissants and pizza presented in Tables (1, 2 and 3). Results cleared that sensory evaluation decreased at high levels of purslane seeds powder, baked(batun salih, croissants and pizza) with $14 \%$ 
purslane seeds powder did not receive any acceptance $12 \pm 0.67,7.2 \pm 0.42$, and $8.7 \pm 0.48$, respectively, while baked(batun salih, croissants and pizza) with $6 \%$ purslane seeds powder were accepted $18.3 \pm 0.48,16.9 \pm 0.32$, and $17 \pm 0.82$, respectively, batun salih and pizza with $10 \%$ purslane seeds powder were accepted $16.5 \pm 0.53$ and $15 \pm 0.67$ but croissants with $10 \%$ purslane seeds powder did not accept $13 \pm 0.47$ as compared to control.

Baked products with $14 \%$ purslane seeds powder did not receive any acceptance, this is may be due to the black color of purslane seeds, while the contents of the batun salih from cumin, and the additives that are placed on the pizza may be responsible for accepting purslane seed powder at $6 \%$ and $10 \%$.

According to Fathnejhad et al.,( 2012), bread containing 10\% purslane seeds powder was higher sensory scores compared to $15 \%$ and $20 \%$ purslane seeds, and found that levels (below 10\%) of pursalne seeds addition, improved sensorial properties of product.

Table (1) : Sensory evaluation of batun salih with purslane seeds (6,10and14\%)

\begin{tabular}{|c|c|c|c|c|}
\hline Treatments & $\begin{array}{c}\text { Aroma } \\
\text { (20 scores) }\end{array}$ & $\begin{array}{c}\text { Taste } \\
\mathbf{( 4 0} \text { scores) }\end{array}$ & $\begin{array}{c}\text { Color } \\
\mathbf{( 2 0} \text { scores) }\end{array}$ & $\begin{array}{c}\text { Overall } \\
\text { Acceptability } \\
\text { (20 scores) }\end{array}$ \\
\hline Control & $20 \pm 0.00^{\mathrm{a}}$ & $39.8 \pm 0.42^{\mathrm{a}}$ & $19.9 \pm 0.32^{\mathrm{a}}$ & $20 \pm 0.00^{\mathrm{a}}$ \\
\hline PSBS1 & $19.6 \pm 0.70^{\mathrm{a}}$ & $39.5 \pm 0.53^{\mathrm{a}}$ & $15.5 \pm 0.53^{\mathrm{b}}$ & $18.3 \pm 0.48^{\mathrm{b}}$ \\
\hline PSBS2 & $18 \pm 0.67^{\mathrm{b}}$ & $38.6 \pm 0.52^{\mathrm{b}}$ & $13 \pm 0.67^{\mathrm{c}}$ & $16.5 \pm 0.53^{\mathrm{c}}$ \\
\hline PSBS3 & $14 \pm 0.94^{\mathrm{c}}$ & $29.1 \pm 0.32^{\mathrm{c}}$ & $9 \pm 0.94^{\mathrm{d}}$ & $12 \pm 0.67^{\mathrm{d}}$ \\
\hline
\end{tabular}

Control:100\% wheat flour, PSBS1: 6\% Purslane seeds powder, PSBS2: 10\% Purslane seeds powder, PSBS3: $14 \%$ Purslane seeds powder. Values are expressed as mean \pm SD. Different letters on the same column represent statistically significant $(\mathrm{P}<0.05)$ difference among means. 
Table (2) : Sensory evaluation of croissants with purslane seeds $(6,10$ and $14 \%)$

\begin{tabular}{|c|c|c|c|c|}
\hline Preatments & $\begin{array}{c}\text { Aroma } \\
\text { (20 scores) }\end{array}$ & $\begin{array}{c}\text { Taste } \\
\mathbf{( 4 0} \text { scores) }\end{array}$ & $\begin{array}{c}\text { Color } \\
\text { (20 scores) }\end{array}$ & $\begin{array}{c}\text { Overall } \\
\text { Acceptability } \\
\text { (20 scores) }\end{array}$ \\
\hline Control & $19.8 \pm 0.42^{\mathrm{a}}$ & $39.9 \pm 0.32^{\mathrm{a}}$ & $20 \pm 0.00^{\mathrm{a}}$ & $20 \pm 0.00^{\mathrm{a}}$ \\
\hline PSC1 & $15.9 \pm 0.32^{\mathrm{b}}$ & $30 \pm 0.67^{\mathrm{b}}$ & $14.9 \pm 0.32^{\mathrm{b}}$ & $16.9 \pm 0.32^{\mathrm{b}}$ \\
\hline PSC2 & $14 \pm 0.67^{\mathrm{c}}$ & $24 \pm 0.94^{\mathrm{c}}$ & $13 \pm 0.47^{\mathrm{c}}$ & $13 \pm 0.47^{\mathrm{c}}$ \\
\hline PSC3 & $10 \pm 0.82^{\mathrm{d}}$ & $15 \pm 0.47^{\mathrm{d}}$ & $7.7 \pm 0.67^{\mathrm{d}}$ & $7.2 \pm 0.42^{\mathrm{d}}$ \\
\hline
\end{tabular}

Control:100\% wheat flour, PSBS1: 6\% Purslane seeds powder, PSBS2: 10\% Purslane seeds powder, PSBS3: 14\% Purslane seeds powder. Values are expressed as mean \pm SD. Different letters on the same column represent statistically significant $(\mathrm{P}<0.05)$ difference among means.

Table (3) : Sensory evaluation of pizza with purslane seeds $(6,10$ and $14 \%)$

\begin{tabular}{|c|c|c|c|c|}
\hline Treatments & $\begin{array}{c}\text { Aroma } \\
\text { (20 scores) }\end{array}$ & $\begin{array}{c}\text { Taste } \\
\text { (40 scores) }\end{array}$ & $\begin{array}{c}\text { Color } \\
\text { (20 scores) }\end{array}$ & $\begin{array}{c}\text { Overall } \\
\text { Acceptability } \\
\text { (20 scores) }\end{array}$ \\
\hline Control & $19.8 \pm 0.42^{\mathrm{a}}$ & $40 \pm 0.00^{\mathrm{a}}$ & $20 \pm 0.00^{\mathrm{a}}$ & $20 \pm 0.00^{\mathrm{a}}$ \\
\hline PSP1 & $19.1 \pm 0.32^{\mathrm{b}}$ & $39.3 \pm 0.48^{\mathrm{b}}$ & $12.3 \pm 0.48^{\mathrm{b}}$ & $17 \pm 0.82^{\mathrm{b}}$ \\
\hline PSP2 & $17.8 \pm 0.92^{\mathrm{c}}$ & $38.1 \pm 0.32^{\mathrm{c}}$ & $9.8 \pm 0.42^{\mathrm{c}}$ & $15 \pm 0.67^{\mathrm{c}}$ \\
\hline PSP3 & $12.6 \pm 0.52^{\mathrm{d}}$ & $29.6 \pm 0.52^{\mathrm{d}}$ & $4.0 \pm 0.67^{\mathrm{d}}$ & $8.7 \pm 0.48^{\mathrm{d}}$ \\
\hline
\end{tabular}

Control:100\% wheat flour, PSBS1: 6\% Purslane seeds powder, PSBS2: 10\% Purslane seeds powder, PSBS3: 14\% Purslane seeds powder. Values are expressed as mean \pm SD. Different letters on the same column represent statistically significant $(\mathrm{P}<0.05)$ difference among means.

\section{Effect of treatments on chemical composition of wheat flour:}

Presented data in Table (4) showed the effect of treatments on chemical composition of wheat flour. Results cleared that increasing the level of purslane seeds powder led to significant increase $(\mathrm{P}<0.05)$ in the content of wheat flour from protein $11.98 \pm 0.01,12.48 \pm 0.02$ and $12.82 \pm 0.01 \%$, respectively, fat $0.71 \pm 0.02, \quad 1.22 \pm 0.01$ and $1.56 \pm 0.02 \%$, respectively, ash $0.55 \pm 0.01$, $1.34 \pm 0.01$ and $1.86 \pm 0.01 \%$, respectively, fiber $0.88 \pm 0.01,1.74 \pm 0.02$ and $2.32 \pm 0.02 \%$, respectively, and significant decreased $(\mathrm{P}<0.05)$ in carbohydrates 
$85.88 \pm 0.03, \quad 83.22 \pm 0.02$ and $81.44 \pm 0.04 \%, \quad$ respectively and calories $397.83 \pm 0.03,393.78 \pm 0.03$ and $391.08 \pm 0.01 \%$, respectively.

In this respect, Naghavi1 et al.,(2011) declared that purslane seeds powder was used to replace 50,100, 150 and $200 \mathrm{~g} \mathrm{kg-}^{1}$ of wheat flour. Protein and fiber contents of supplemented flours increased as the purslane seeds powder increased.

These results are in harmonization with Almasoud and Salem, ( 2014) who found that the addition of purslane powder led to significant increase in the protein, ash an fiber contents of crackers as the amount of purslane powder increased, therefore, Hussien and Salem,( 2016) found that the addition of purslane led to significant increase the protein, ash and fiber contents of extruded snacks .

Table (4): Chemical composition of wheat flour(ex72\%) with purslane seeds powder $/ 100 \mathrm{~g}$

\begin{tabular}{|c|c|c|c|c|c|c|}
\hline Composition & 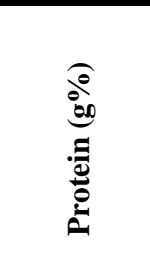 & 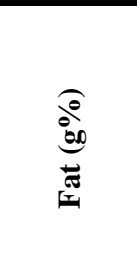 & 岳 & 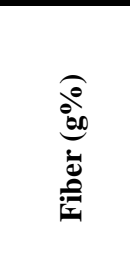 & 苞 & 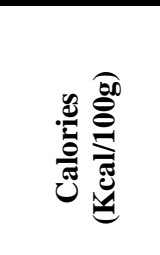 \\
\hline $\begin{array}{l}100 \% \text { wheat } \\
\text { flour }\end{array}$ & $11.98 \pm 0.01^{\mathrm{c}}$ & $0.71 \pm 0.02^{\mathrm{c}}$ & $0.55 \pm 0.01^{\mathrm{c}}$ & $0.88 \pm 0.01^{\mathrm{c}}$ & $85.88 \pm 0.03^{\mathrm{a}}$ & $397.83 \pm 0.03^{\mathrm{a}}$ \\
\hline $\begin{array}{c}94 \% \text { wheat } \\
\text { flour+ } 6 \% \\
\text { Purslane seeds } \\
\text { powder }\end{array}$ & $12.48 \pm 0.02^{\mathrm{b}}$ & $1.22 \pm 0.01^{\mathrm{b}}$ & $1.34 \pm 0.01^{\mathrm{b}}$ & $1.74 \pm 0.02^{\mathrm{b}}$ & $83.22 \pm 0.02^{\mathrm{b}}$ & $393.78 \pm 0.03^{\mathrm{b}}$ \\
\hline $\begin{array}{c}90 \% \text { wheat } \\
\text { flour+ } 10 \% \\
\text { Purslane seeds } \\
\text { powder }\end{array}$ & $12.82 \pm 0.01^{\mathrm{a}}$ & $1.56 \pm 0.02^{\mathrm{a}}$ & $1.86 \pm 0.01^{\mathrm{a}}$ & $2.32 \pm 0.02^{\mathrm{a}}$ & $81.44 \pm 0.04^{\mathrm{c}}$ & $391.08 \pm 0.01^{\mathrm{c}}$ \\
\hline
\end{tabular}

means of three determinations

Different letters on the same column represent statistically significant $(\mathrm{P}<0.05)$ difference among means.

\section{Effect of treatments on rheological properties for wheat flour (extraction $72 \%)$ :}

Table (5), and Figure (1and2) showed the effect of treatments on farinograph and extensograph parameters, the addition of purslane seeds led to decrease in the rate of arrival time $2.00,1.50$ and $1.50 \mathrm{~min}$, respectively, dough development time $3.00,2.50$ and $2.50 \mathrm{~min}$, respectively, mixing 
tolerance index 60,45and $40 \mathrm{BU}$, respectively, resistance to extension 260, 235 and $240 \mathrm{BU}$, respectively, extensibility 90,80 and $80 \mathrm{~mm}$, respectively, and energy 43,41and $38 \mathrm{~cm}^{2}$, respectively, while, the addition of purslane seeds led to increase in water absorption 59, 62 and $65 \%$, respectively, and dough stability4.50, 6.50 and $8.50 \mathrm{~min}$, respectively, maximum height 260,320 and $347 \mathrm{BU}$, respectively, and proportional number 2.88, 2.93 and 3.00, respectively.

The previous results may be due to the change in the content of the wheat flour due to the addition of purslane seeds, which led to an increase in the level of protein and fiber and decrease in gluten.

The development time of the dough is directly proportional to the increase in gluten content (Abdullah et al.,2016).

In this respect, Melilli et al.,( 2020) showed that levels (5, 10and 15\%) of pursalne led to an increase in water absorption and dough stability.

Table (5): Rheological properties of wheat flour with purslane seeds powder

\begin{tabular}{|c|c|c|c|}
\hline Tests & $100 \%$ wheat flour & $\begin{array}{l}94 \% \text { wheat flour }+6 \% \\
\text { Purslane seeds powder }\end{array}$ & $\begin{array}{c}90 \% \text { wheat flour }{ }^{+} \\
10 \% \text { Purslane seeds } \\
\text { powder }\end{array}$ \\
\hline \multicolumn{4}{|c|}{ Farinograph parameters } \\
\hline $\begin{array}{c}\text { Water absorption } \\
\text { (\%) }\end{array}$ & 59 & 62 & 65 \\
\hline Arrival time (min) & 2.00 & 1.50 & 1.50 \\
\hline $\begin{array}{l}\text { Dough development } \\
\text { time(min) }\end{array}$ & 3.00 & 2.50 & 2.50 \\
\hline Dough stability (min) & 4.50 & 6.50 & 8.50 \\
\hline $\begin{array}{l}\text { Mixing tolerance } \\
\text { index (BU) }\end{array}$ & 60 & 45 & 40 \\
\hline \multicolumn{4}{|c|}{ Extensograph parameters } \\
\hline $\begin{array}{l}\text { Resistance to } \\
\text { extension } \\
\text { R50(BU) }\end{array}$ & 260 & 235 & 240 \\
\hline Extensibility (mm) & 90 & 80 & 80 \\
\hline Energy $\left(\mathrm{cm}^{2}\right)$ & 43 & 41 & 38 \\
\hline $\begin{array}{l}\text { maximum height } \\
\text { (BU) }\end{array}$ & 260 & 320 & 347 \\
\hline $\begin{array}{c}\text { Proportional } \\
\text { number } \\
\text { (BU/mm) }\end{array}$ & 2.88 & 2.93 & 3.00 \\
\hline
\end{tabular}




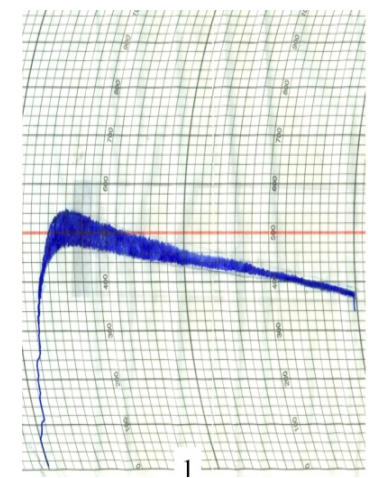

$100 \%$ wheat flour(ex72\%)

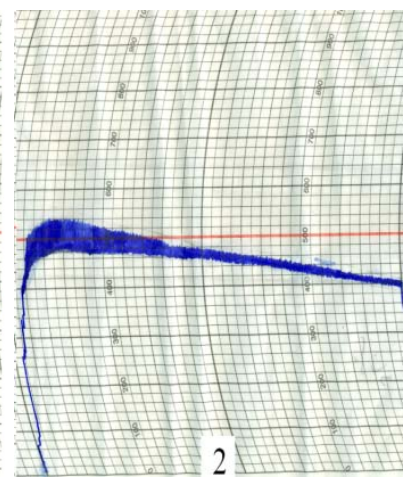

$94 \%$ wheat flour(ex $72 \%)+$ $6 \%$ Purslane seeds powder

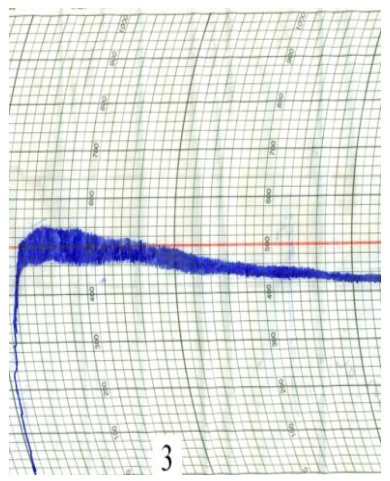

$90 \%$ wheat flour(ex72\%)+ $10 \%$ Purslane seeds powder

Fig. (1): Farinograph parameters of wheat flour(ex72\%) with purslane seeds powder.
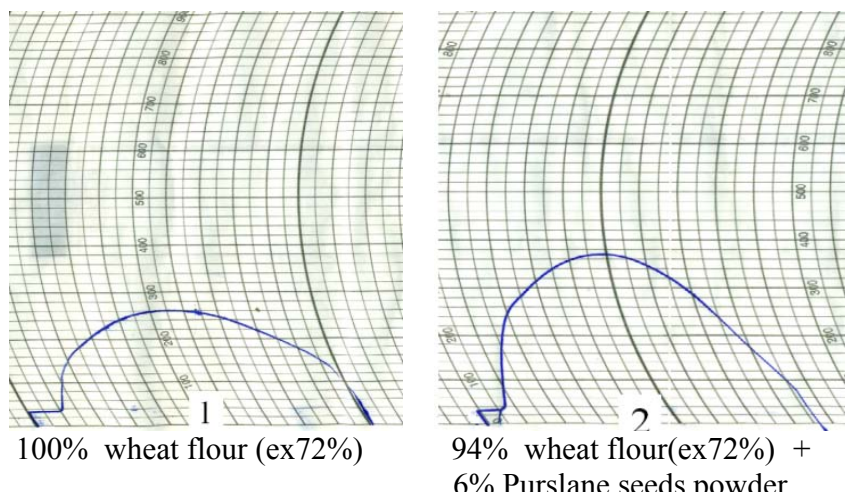

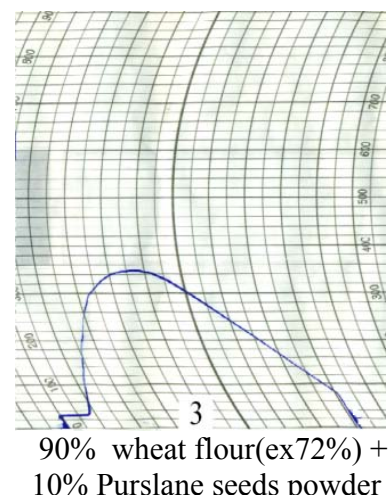

$10 \%$ Purslane seeds powder

Fig. (2): Extensograph parameters of wheat flour(ex72\%) with purslane seeds powder.

\section{Effect of purslane seeds powder on final body weight and body weight gain(BWG \%) of the experimental rat groups:}

Data in Table (6) showed no significant decrease $(\mathrm{p}<0.05)$ in body weight gain (BWG\%) between control group ( $30.86 \pm 3.63 \%)$ and PS1(6\% purslane seeds powder) $(29.22 \pm 2.41 \%)$, while there was significant decrease $(\mathrm{p}<0.05)$ between control group and PS2 $(10 \%$ Purslane seeds powder $)$ $(27.58 \pm 3.27 \%)$.

In this respect , Esmaillzadeh et al., (2015) showed that purslane seeds consumption resulted in a significant reduction in weight. On the other hand, Hussein, (2010) reported that purslane ethanolic extract showed effects anti obesity and anti-diabetic in rats fed a high fat obesity-induced diet. High content of flavonoids, phenolic compounds, melatonin and omega-3 fatty acids found in purslane ethanolic extract may be responsible for these effects. 
Table(6): Effect of purslane seeds powder on final body weight and body weight gain $(\mathrm{BWG} \%)$ of the experimental rat groups

\begin{tabular}{|c|c|c|c|}
\hline Groups & Initial body weight (g) & Final body weight(g) & BWG(\%) \\
\hline C & $160.00 \pm 3.16^{\mathrm{a}}$ & $209.37 \pm 4.10^{\mathrm{a}}$ & $30.86 \pm 3.63^{\mathrm{a}}$ \\
\hline PS1 & $160.00 \pm 2.39^{\mathrm{a}}$ & $206.75 \pm 2.43^{\mathrm{ab}}$ & $29.22 \pm 2.41^{\mathrm{ab}}$ \\
\hline PS2 & $160.00 \pm 3.11^{\mathrm{a}}$ & $204.12 \pm 3.44^{\mathrm{b}}$ & $27.58 \pm 3.27^{\mathrm{b}}$ \\
\hline
\end{tabular}

Values are expressed as means \pm SD for 7 rats in each group , $\mathrm{C}=$ control group, PS1 $=6 \%$ Purslane seeds powder, $\mathrm{PS} 2=10 \%$ Purslane seeds powder. Different letters on the same column represent statistically significant $(\mathrm{P}<0.05)$ difference among means.

\section{Effect of purslane seeds on serum lipid profile of the experimental rat groups:}

Data in Table (7) showed significant decrease $(\mathrm{p}<0.05)$ between $\mathrm{C}$ group and groups PS1(6\% Purslane seeds powder) , PS2(10\% Purslane seeds powder) in cholesterol $107.80 \pm 1.19,105.17 \pm 1.95$ and $103.17 \pm 1.12 \mathrm{mg} / \mathrm{dI}$, respectively, triglycerides $65.80 \pm 1.19,63.92 \pm 1.50$ and $62.30 \pm 1.06 \mathrm{mg} / \mathrm{dI}$, respectively, and Low density lipoprotein-cholesterol 43.09 $\pm 0.97,40.84 \pm 3.92$ and $31.66 \pm 1.92 \mathrm{mg} / \mathrm{dI}$, respectively, the results also showed significant increase $(\mathrm{p}<0.05)$ between $\mathrm{C}$ group and PS1, PS2 groups in high density lipoprotein-cholesterol 51.55 $\pm 1.03,53.92 \pm 2.13$ and $59.05 \pm 1.66 \mathrm{mg} / \mathrm{dI}$, respectively.

These results are in harmonization with Besong et al., (2011) who found that consumption of purslane for 4 weeks reduced plasma TC and LDL-c but HDL-c levels were increased, In this concern, Soo-Jung et al.,(2011) who found that the levels of TC and LDL-C decreased significantly for the group fed the $10 \%$ purslane powder in comparison with the group fed the 5\% purslane powder, also Ghahramani et al., (2016) reported that the serum TC, TG and LDL levels decreased significantly in diabetic rats after purslane seeds treatment.

In this respect, Esmaillzadeh et al., (2015) reported that the effect of purslane intake on lowering TG levels might be explained by its high content of omega-3 fatty acids. Purslane seeds are rich sources of alpha-lineoic acid (omega-3). It also contains substantial amounts of dietary fibre and natural antioxidants such as tocopherols (Naghavi1 et al., 2011).

Human subjects suggest an association between dietary intake of polyunsaturated fatty acids, specifically omega-3 fatty acids and improved 
plasma HDL-c for causing a reduction in LDL-c. The cholesterol lowering effect of purslane may be attributed to the combined effect of omega-3 fatty acids and soluble fiber (pectin) since purslane is rich in w-3 fatty and pectin (Besong et al., 2011).

Table (7): Effect of purslane seeds powder on serum lipid profile of the experimental rat groups

\begin{tabular}{|c|c|c|c|c|}
\hline Groups & $\begin{array}{c}\text { TC } \\
(\mathbf{m g} / \mathbf{d I})\end{array}$ & $\begin{array}{c}\text { TG } \\
\text { (mg/dI) }\end{array}$ & $\begin{array}{c}\text { HDL-c } \\
\text { (mg/dI) }\end{array}$ & $\begin{array}{c}\text { LDL-c } \\
\text { (mg/dI) }\end{array}$ \\
\hline C & $107.80 \pm 1.19^{\mathrm{a}}$ & $65.80 \pm 1.19^{\mathrm{a}}$ & $51.55 \pm 1.03^{\mathrm{c}}$ & $43.09 \pm 0.97^{\mathrm{a}}$ \\
\hline PS1 & $105.17 \pm 1.95^{\mathrm{b}}$ & $63.92 \pm 1.50^{\mathrm{b}}$ & $53.92 \pm 2.13^{\mathrm{b}}$ & $40.84 \pm 3.92^{\mathrm{b}}$ \\
\hline PS2 & $103.17 \pm 1.12^{\mathrm{b}}$ & $62.30 \pm 1.06^{\mathrm{c}}$ & $59.05 \pm 1.66^{\mathrm{a}}$ & $31.66 \pm 1.92^{\mathrm{c}}$ \\
\hline
\end{tabular}

Values are expressed as means \pm SD for 7 rats in each group, $\mathrm{C}=$ control group, PS1 $=6 \%$ Purslane seeds powder,PS $2=10 \%$ Purslane seeds powder.

Different letters on the same column represent statistically significant $(\mathrm{P}<0.05)$ difference among means.

\section{Effect of purslane seeds on liver functions of the experimental rat groups:}

Data in Table (8) showed significant decrease $(\mathrm{p}<0.05)$ between $\mathrm{C}$ group(control) and groups PS1(6\% Purslane seeds powder), PS2(10\% purslane seeds powder) in AST $37.97 \pm 0.74,36.10 \pm 0.92$ and $33.97 \pm 0.51 \mathrm{U} / \mathrm{L}$, respectively, ALT $26.47 \pm 0.83,25.10 \pm 0.92$ and $23.97 \pm 0.74 \mathrm{U} / \mathrm{L}$, respectively, and ALP 47.72 $\pm 0.99,46.10 \pm 1.30$ and $44.85 \pm 0.46 \mathrm{U} / \mathrm{L}$, respectively.

The current study is consistent with Askaripour et al.,(2016) showed that purslane decreased hepatic enzymes, and Kamel et al., (2017) who found that in groups treated with purslane seeds extract, activity of liver enzymes were reduced also Najafabadi et al.,(2015) who found that purslane seeds consumption after 8 weeks significantly reduced AST,ALT, and Soo-Jung et al.,(2011) reported that the activities of AST,ALT, ALP decreased significantly for the groups fed the purslane powder.

On the other hand, purslane seeds are reportedly more effective in antioxidation than those from other herbs (Guo et al, 2016). The purslane seeds showed significant decrease in hepatic enzymes including ALT and AST levels in rats. This effect may be related to antioxidant activity of purslane seeds. The constituents of purslane such as flavonoids (quercetin), omega-3, ascorbic acid, B-carotene and glutathione have antioxidant activity (Ghahramani et al., 2016). 
Table (8): Effect of purslane seeds powder on liver enzymes of the experimental rat groups

\begin{tabular}{|c|c|c|c|}
\hline Groups & AST (U/L) & ALT (U/L) & ALP (U/L) \\
\hline C & $37.97 \pm 0.74^{\mathrm{a}}$ & $26.47 \pm 0.83^{\mathrm{a}}$ & $47.72 \pm 0.99^{\mathrm{a}}$ \\
\hline PS1 & $36.10 \pm 0.92^{\mathrm{b}}$ & $25.10 \pm 0.92^{\mathrm{b}}$ & $46.10 \pm 1.30^{\mathrm{b}}$ \\
\hline PS2 & $33.97 \pm 0.51^{\mathrm{c}}$ & $23.97 \pm 0.74^{\mathrm{c}}$ & $44.85 \pm 0.46^{\mathrm{c}}$ \\
\hline
\end{tabular}

Values are expressed as means \pm SD for 7 rats in each group , $C=$ control group, $\mathrm{PS} 1=6 \%$ Purslane seeds powder, PS2 $=10 \%$ Purslane seeds powder.

Different letters on the same column represent statistically significant $(\mathrm{P}<0.05)$ difference among means.

\section{Effect of purslane seeds on kidney functions of the experimental rat groups:}

Data in Table (9) showed no significant decrease $(\mathrm{p}<0.05)$ between $\mathrm{C}$ (control group) and PS1(6\% Purslane seeds powder) in urea $29.47 \pm 1.59$ and $29.22 \pm 0.74 \mathrm{mg} / \mathrm{dI}$ respectively, and creatinine $0.82 \pm 0.01$ and $0.81+0.01 \mathrm{mg} / \mathrm{dI}$, respectively, while there was significant decrease $(\mathrm{p}<0.05)$ between $\mathrm{C}$ (control group) and PS2(10\% Purslane seeds powder) in urea $29.47 \pm 1.59$ and $28.10 \pm 1.16 \mathrm{mg} / \mathrm{dI}$, respectively, and creatinine $0.82 \pm 0.01$ and $0.80 \pm 0.01 \mathrm{mg} / \mathrm{dI}$, respectively.

The present study agree with Dkhil et al.,(2011) who showed that purslane caused significant decrease in urea and creatinine, and Dehghan et al.,( 2016) who found that creatinine, urea, in the purslane seeds group were significantly decreased compared to the pre experimental levels.

The purslane seeds showed significantly decreased urea in rats. This effect may be related to antioxidant activity of purslane seeds. The constituents of purslane such as flavonoids (quercetin), omega-3, ascorbic acid, B-carotene and glutathione have antioxidant activity (Ghahramani et al., 2016).

Table (9): Effect of purslane seeds powder on urea and creatinine of the experimental rat groups

\begin{tabular}{|c|c|c|}
\hline Groups & Urea( mg/dI) & Creatinine( mg/dI) \\
\hline C & $29.47 \pm 1.59^{\mathrm{a}}$ & $0.82 \pm 0.01^{\mathrm{a}}$ \\
\hline PS1 & $29.22 \pm 0.74^{\mathrm{ab}}$ & $0.81 \pm 0.01^{\mathrm{ab}}$ \\
\hline PS2 & $28.10 \pm 1.16^{\mathrm{b}}$ & $0.80 \pm 0.01^{\mathrm{b}}$ \\
\hline
\end{tabular}

Values are expressed as means $\pm \mathrm{SD}$ for 7 rats in each group , $\mathrm{C}=$ control group, $\mathrm{PS} 1=6 \%$ Purslane seeds powder, PS2 $=10 \%$ Purslane seeds powder.

Different letters on the same column represent statistically significant $(\mathrm{P}<0.05)$

difference among means. 


\section{Effect of purslane seeds on blood glucose of the experimental rat groups:}

Data in Table (10) showed no significant decrease $(\mathrm{p}<0.05)$ between $\mathrm{C}$ (control group) and groups PS1, PS2 in blood glucose 100.00 \pm 0.58 , $99.57 \pm 0.53,99.43 \pm 0.53 \mathrm{mg} / \mathrm{dI}$, respectively.

The present study agree with Cui et al.,(2005) who reported that purslane has no bad influence on the blood glucose in normal rats. Purslane is a general tissue protective, as evidenced by increasing $\beta$-cell mass and therefore improved the glucose metabolism (Ramadan et al.,2017).

Table (10): Effect of purslane seeds powder on serum blood glucose of the

experimental rat groups

\begin{tabular}{|c|c|}
\hline Groups & Blood glucose( mg/dI) \\
\hline C & $100.00 \pm 0.58^{\mathrm{a}}$ \\
\hline PS1 & $99.57 \pm 0.53^{\mathrm{a}}$ \\
\hline PS2 & $99.43 \pm 0.53^{\mathrm{a}}$ \\
\hline
\end{tabular}

Values are expressed as means \pm SD for 7 rats in each group , $\mathrm{C}=$ control group,

$\mathrm{PS} 1=6 \%$ Purslane seeds powder, $\mathrm{PS} 2=10 \%$ Purslane seeds powder.

Different letters on the same column represent statistically significant $(\mathrm{P}<0.05)$

difference among means.

\section{Effect of purslane seeds on histopathological of liver:}

Microscopic pictures of liver sections (Figures 3,4 and 5) showing normal hepatocytes $(\mathrm{H})$ in well organized radially arranged hepatic cords around central vein (CV) with normally appeared sinusoids (S) and von kupffer cells ( arrows) in control group, PS1group (rats fed on 6\% purslane seeds powder) and PS2group (rats fed on 10\% purslane seeds powder).

In this respect, the histopathological examination of liver showed that purslane reduced the incidence of liver lesions signs of hepatic toxicity and substantiates its use in various liver disorders as hepato protection (Abd ElAziz et al., 2014). 


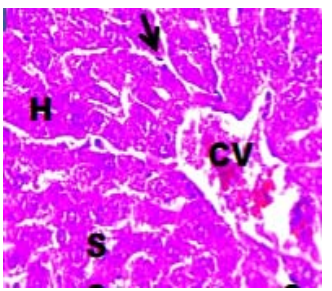

Fig. (3): Liver of rat from group c (H\&E,X:200).

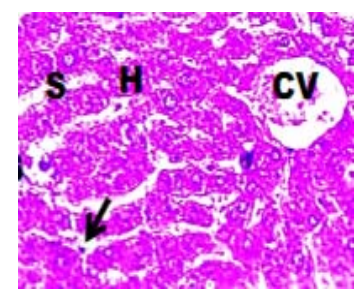

Fig. (4): Liver of rat from PS1group (H\&E,X:200).

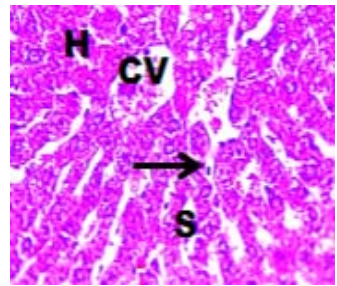

Fig. (5): Liver of rat from PS2group (H\&E,X:200).

\section{Effect of purslane seeds on histopathological of kidney:}

Microscopic pictures of kidney sections (Figures 6,7and 8) showing normal Glomeruli $(\mathrm{G})$ and renal tubules $(\mathrm{T})$ in control group , PS1 group (rats fed on $6 \%$ purslane seeds powder) and PS2 group (rats fed on $10 \%$ purslane seeds powder).

In this respect ,the histopathological examination of kidney showed that Purslane is useful in controlling kidney injury in drug induced nephrotoxicity (Ganiyu et al.,2015).

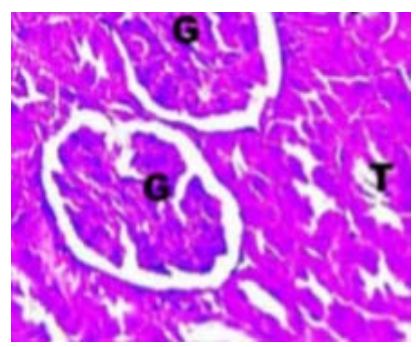

Fig.(6): kidney of rat from group c (H\&E,X:200).

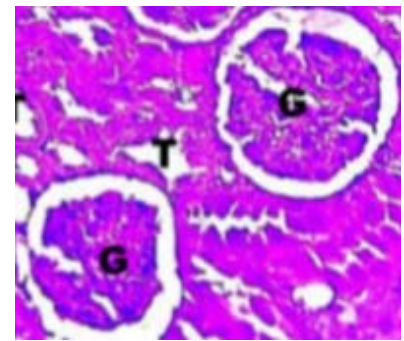

Fig. (7): kidney of rat from PS1 group (H\&E,X:200).

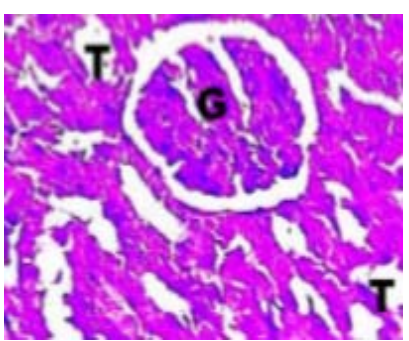

Fig. (8): kidney of rat from PS2group (H\&E,X:200).

\section{Effect of purslane seeds on histopathological of heart:}

Microscopic pictures of heart sections (Figures 9,10 and 11) showing normal Appearance of longitudinally (L) and crossly (C) sectioned cardiac muscle fibers in control group , PS1group (rats fed on 6\% purslane seeds powder) and PS2 group (rats fed on 10\% purslane seeds powder). 
According to Fathnejhad et al.,( 2012), purslane seeds have beneficial health effect on the body specially in preventing cardiovascular diseases, because it contains omega- 3 , omega- 6 fatty acids , antioxidants, tocopherols and dietary fiber.

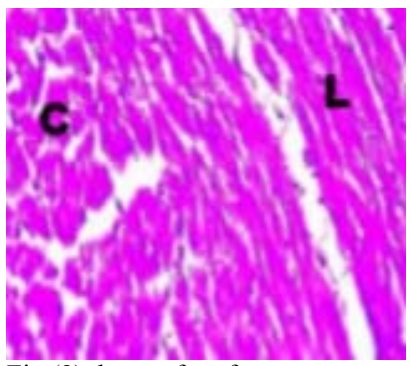

Fig.(9): heart of rat from group c (H\&E,X:200).

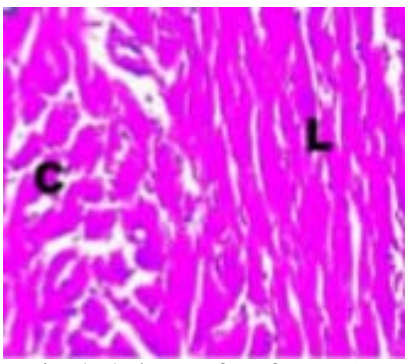

Fig. (10): heart of rat from PS1group Fig. (11): heart of rat from PS2group (H\&E,X:200).

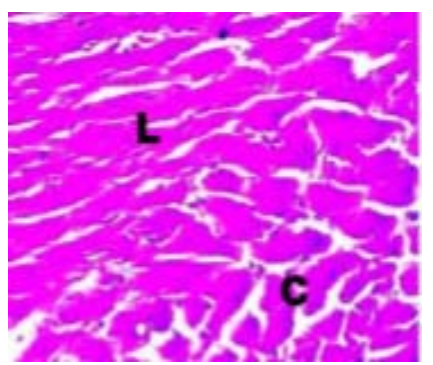

(H\&E,X:200).

\section{Conclusion}

The results in the present study showed that the addition of purslane seeds powder resulted in an increase in protein, fat, ash and fiber, and decrease in carbohydrate and energy. The results of the sensory tests showed not accepted of supplemented baked products (batun salih, croissants, pizza) with $14 \%$ purslane seeds powder. The results of the rheological tests showed an increase in water absorption, dough stability, proportional number and maximum height, and decrease in arrival time, dough development time, resistance to extension, extensibility, and energy. Also the results showed decrease in the weight gain, urea, creatinine, serum blood glucose, TG, TG, LDL-c, AST, ALT and ALP with increase in HDL-c. The results of histopathological examination showed that there were no bad effects of the purslane seeds powder on the liver, kidney and heart. So the current study recommends supplementing wheat flour (extraction of $72 \%$ ) when making baked products with purslane seeds powder, with more studies being necessary. 


\section{References}

A.A.C.C. (1995): American Association of Cereal Chemists. Approved Methods of the American Association of Cereal Chemists. v.1 and v.2, 9th edn. Saint Paul, USA: AACC.

A.A.C.C.(2002): Approved Method of American Association of Cereal Chemists, Published by American Association of Cereal Chemists , Ins. St. Paul, Minnesota, USA.

A.O.A.C. (2000): Association of Official Agricultural Chemists. Official Method of Analysis. $17^{\text {th }}$ Ed. Vol. 11. Washington U.S. A.

Abd El-Aziz, H. A. ;Sobhy, M.H.; Ahmed, K.A.; Abd El hameed, A. K. ; Rahman, Z.A. and Hassan, W.A.(2014):" Chemical and remedial effects of portulaca oleracea plant". Life Sci J. ,11(6):31-42.

Abdalla, H. M.(2010):" Purslane extract effects on obesity-induced diabetic rats fed a high-fat diet" .Mal J Nutr. ,16(3): 419 - 429.

Abdullah, A.B.; Fadle, J.A. and Assaj, K.M.(2016):" Characteristics and bread-making quality of wheat and quinoa flour blends " Assiut J. Agric. Sci., 47 (5) :95-106.

Allen,C.C. (1974) : Cholesterol enzymatic colorimetric method .J. of Clin. Chem., (20) :470.

Almasoud, A. G. and Salem, E. (2014): "Nutritional quality of purslane and its crackers". Middle East Journal of Applied Sciences, 4 (3): 448454.

Askaripour, M.; Tabatabaei, R.; Hosseini,F.; Rashno,M. and Ghaderi,S.(2016):" Effects of aqueous extract of purslane (Portulaca oleracea) on hepatic enzymes in two models of renal ischemia-reperfusion injury in rats". Zahedan J Res Med Sci., 18(2):29- 31.

Bancroft, J. D. and Gamble, M.(2007):" Theory and practice of histological techniques . $5^{\text {th }}$ Ed; Churchill Livingstone, London, UK, p. 125138. 
Belfield, A. and Goldberg ,D.M. (1971) :"Alkaline phosphatase colorimetric method" . J. of Enzyme, (12):561.

Besong, S.A.; Ezekwe, M.O. and Ezekwe, E.I.(2011): " Evaluating the effects of freeze-dried supplements of purslane (Portulaca oleracea) on blood lipids in hypercholesterolemic adults". International Journal of Nutrition and Metabolism , 3(4) : 43-49.

Chapman, D.G.; Gastilla, R. and Campbell, J.A.(1959):"Evaluation of protein in food 1-A method for the determination of protein efficiency ratio . Can. J. Biochem. Physiol, 37:679- 686.

Chugh, V.; Mishra, V.; Dwivedi, S.V. and Sharma,K.D.(2019):" Purslane (Portulaca oleracea L.): An underutilized wonder plant with potential pharmacological value". The Pharma Innovation Journal , 8(6): 236-246.

Cui, M. Z.; Liu, H. and Li, C. Y.(2005) :" Changes of blood glucose in diabetic rats and the interventional effect of purslane ". Chinese Journal of Clinical Rehabilitation, 9(27):92-93.

Dehghan, F.; Soori, R.; Gholami, K.; Abolmaesoomi, M.; Yusof, A.; Sekaran Muniandy, S.; Heidarzadeh, S.; Farzanegi, P. and Azarbayjani, M. A.(2016): " Purslane (Portulaca oleracea) seed consumption and aerobic training improves biomarkers associated with atherosclerosis in women with type 2 diabetes (T2D)". Sci. Rep., 6: 37819.

Dkhil, M.A.; Abdel Moniem, A.E.; Al-Quraishy, S. and Saleh,R.A. (2011): "Antioxidant effect of purslane (Portulaca oleracea) and its mechanism of action". Journal of Medicinal Plants Research, 5(9): 1589-1563.

El Gindy, A. A.(2017): " Chemical, technological and biochemical studies of purslane leaves" . Current Science International, 6(3): 540-551.

Esmaillzadeh, A.; Zakizadeh, E.; Faghihimani, E.; Gohari, M. and Jazayeri, S.(2015):" The effect of purslane seeds on glycemic status and lipid profiles of persons with type 2 diabetes: A randomized controlled cross-over clinical trial". J Res Med Sci., 20(1): 47-53.

Fassati, P. and Prencipe, L. (1982): "Triglyceride enzymatic colorimetric method ".J.of Clin. Chem., 28: 2077. 
Fathnejhad, R..; Peighambardoust, H.; Azadmard, S.; Nemati, M.; Rafat, A. and Naghavi, S.(2012): "The effect of purslane powder on chemical characteristics, fatty acids profile and sensory quality of bread". Iranian Journal of Nutrition Sciences \& Food Technology, 7(3): 11-18.

Friedewable ,W.;Levy , J. and Fredrickson, D. (1972) : "Estimation of the concentration of low density lipoprptein cholesterol in plasma". Clin. Chem., 18 (6):499-502.

Ganiyu, F.; Haruna, A. and Ali Sherriff, M.(2015) : " An assessment of the effect of methanolic extract of Portulaca oleracea on potassium bromate induced nephrotoxicity in mature wistar rats" Int. J. Anat. Physiol., 4(5): 077080 .

Ghahramani, R.; Eidi, M.; Ahmadian, H.; Nomani, M.; Abbasi, R.; Alipour, M. and Anissian, A.(2016): " Anti-diabetic effect of Portulaca oleracea (purslane) seeds in alloxan-induced diabetic rats". International Journal of Medical Laboratory, 3(4):282-289.

Guo, G.; Yue, L.; Fan, S.; Jing, S. and Yan, L.(2016): "Antioxidant and antiproliferative activities of purslane seed oil". J Hypertens (Los Angel), 5(2): 218 .

Henry ,R .J. (1974) : Clinical Chemistry Principles and Techniques . 2 nd Ed. Harper and Publisher. New York.

Hussein, A.M.(2010): "Purslane extract effects on obesity-induced diabetic rats fed a high-fat diet" Mal J Nutr, 16(3): 419 - 429

Hussien, H.A. and Salem, E.M. (2016): "Development of gluten free snacks fortified with purslane (Portulaca oleracea) powder" .food and nutr sci,4(6): 136- 144.

Kamel, I.S.; El- Sherbini, E.; Hassan,H.A. and El-Ghareeb, M.S.(2017): " Biochemical studies on hepatocellular carcinoma in male rats: the protective role of purslane seeds extract". World Journal of Pharmacy and Pharmaceutical Sciences, 6(9): 41-56.

Lawrence, R.D. (1965): The diabetic life. J. and A. Churchill, LTD. London. 
Lopez, M.F. (1977) :" HDL-cholesterol colorimetric method" .J.of Clin. Chem., 230: 282.

Martins, W.B.; Rodrigues, S.A.; Silva, H.K.; Dantas, C.G.; Júnior, W.D.; Filho, L.X.; Cardoso, J.C. and Gomes, M.Z.(2016): " Neuroprotective effect of Portulaca oleracea extracts against 6-hydroxydopamine-induced lesion of dopaminergic neurons". An Acad Bras Cienc, 88 (3): 1439-1450.

Melilli, M.G.; Stefano, V.D.; Sciacca, F.; Pagliaro, A.; Bognanni, R.; Scandurra, S.; Virzì, N.; Gentile, C. and Palumbo, M.(2020):" Improvement of fatty acid profile in durum wheat breads supplemented with Portulaca oleracea L. Quality traits of purslane-fortified bread foods, 9 (6): 764.

Naghavi1,S.;. Mogaddam,M.J.; Peighambardoust,S.H.;Ghaffari,A.O. and Damirchi , S.A.(2011): " Fortification of wheat flour with purslane seed powder: Studying flour characteristics and dough rheological properties". Journal of food research (university of Tabriz) fall , 21 (3): 281 - 293.

Najafabadi,E.A.;Dehghani,A.; Behradmanesh,S. and Najarzadeh,A. (2015):" The effect of purslane seeds on fasting blood glucose and serum liver enzymes in patients with nonalcoholic fatty livers". Iranian journal of diabetes and obesity, 7(4): 163-171.

Pattn ,C.J. and Crouch ,S.R. (1977):"Enzymatic determination of urea". J.Anal.Chem.,49: 464-469.

Rahimi, V.B.; Ajam, F.; Rakhshandeh, H. and Askari, V.R.(2019): "A pharmacological review on Portulaca oleracea L.: focusing on antiinflammatory, anti- oxidant, immuno-modulatory and antitumor activities".J. Phamacopuncture, 22(1): 7-15.

Ramadan, B. K.; Schaalan, M. F. and Tolba, A.M.(2017) : " Hypoglycemic and pancreatic protective effects of Portulaca oleracea extract in alloxan induced diabetic rats" . BMC Complementary and Alternative Medicine, 17(37) : 1-10.

Reeves, P.G.; Nielsen, F.H; Fahey, G.C. and AIN, J.r. (1993): "purified diets for laboratory rodents: final report of the American Institute of Nutrition ad hoc writing committee on the reformulation of the AIN-76A rodent diet". J. Nutr., 123:1939-1951. 
Reitman,S. and Frankel,S. (1957) : "Colorimetric determination of glutamic oxalacetic transaminase (GOT) activity" .Amer.J.Clin.path., 28:56.

Saba, N, H .(1995): "Cooking, science and art". Dar EL-Maaref, Cairo, $591,594,606$.

Safaeian, L.; Baniahmad, B.; Esfandiari, Z. and Alavi, S.A.(2018): " seeds extract does not prevent dexamethasone-induced hypertension in rats Portulaca oleracea" . J Herbmed Pharmacol, 7(1): 8-12.

Sari, H. S. and Sariçoban, C.(2016): " Effects of purslane, stinging nettle and flax seed flours on some physicochemical and sensory properties of naturally fermented turkish style semi-dry sausage(sucuk)". International Journal of Applied Science and Technology, 6(3):67-78.

Seif, M. M.; Madboli, A.; Marrez, D.A. and Aboulthana, W.M.(2019) :" Hepato-renal protective effects of egyptian purslane extract against experimental cadmium toxicity in rats with special emphasis on the functional and histopathological changes".J. Toxicol Rep., 6: 625-631

Soo-Jung, L. ; Jung-Hye, S.; Min-Jung, K.; Mi-Ju, K.; Sung-Hee, K.and Nak-Ju, S.(2011): "Effects of Portulaca oleracea powder on the lipid levels of rats fed a hypercholesterolemia inducing diet". Preventive Nutrition and Food Science, 16(3) : 202-209.

SPSS (1999) : SPSS-PC for the IBM PC/XT computer. version11.0 SPSS Inc., U.S.A.

Trinder,P.(1959) :" Determination of blood glucose using 4aminophenazone" Journal of Clinical Pathology, 22(2):246.

Uddin,K.; Juraimi, A.; Hossain, S.; Un Nahar, A.; Ali, E. and Rahman, M.(2014): " Purslane weed (Portulaca oleracea): a prospective plant source of nutrition, omega-3 fatty acid, and antioxidant attributes" . The Scientific World Journal , 1-6. 


\section{الملخص}

تأثير التدعيم ببذور الرجلة علي دقيق القمح واستخدامه في عمل بعض المخبوزات

يهدف البحث الحالي إلي دراسة التأثيرات الناتجة من تدعيم دقيق القمح ( استخلاص بr \% )

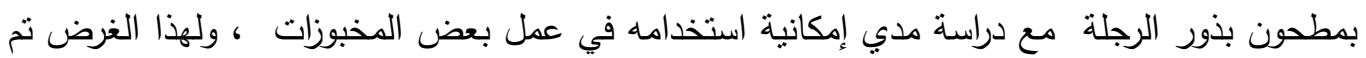

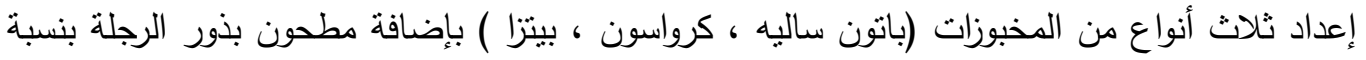

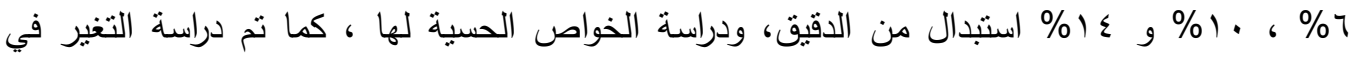

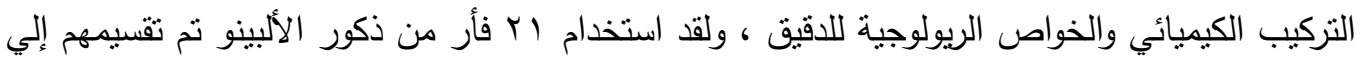

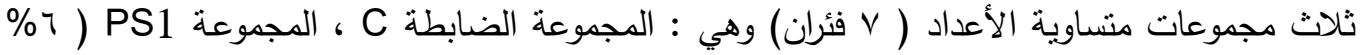

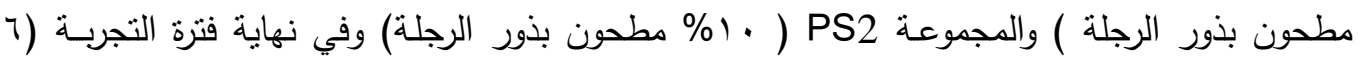

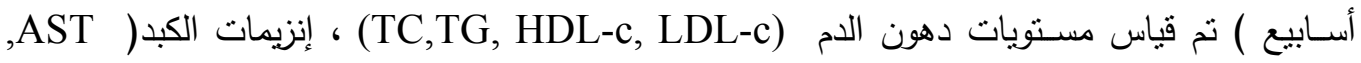

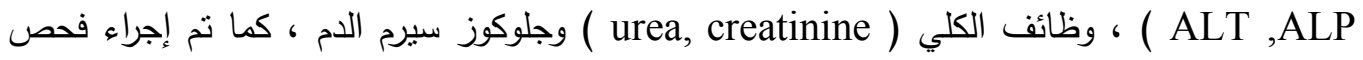

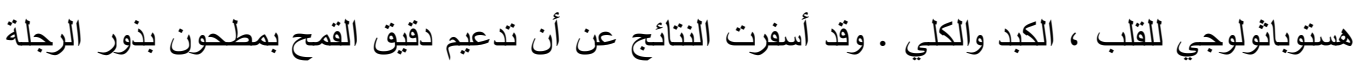

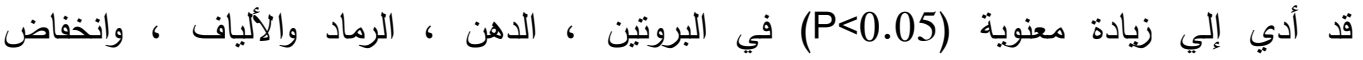

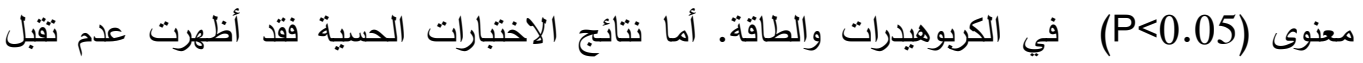

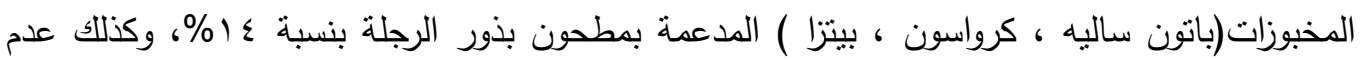

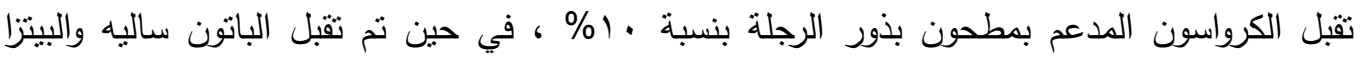
المدعمة بنسبة 7\% و ·. (\% مطحون بذور رجلة . و أظهرت نتائج اختبارات الفارينوجراف و

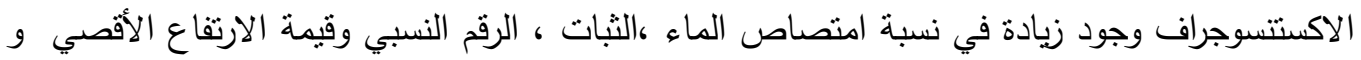

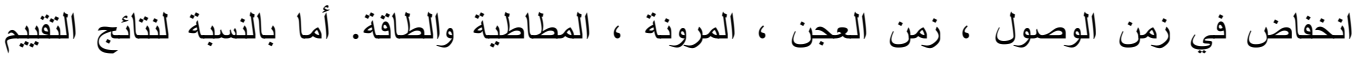

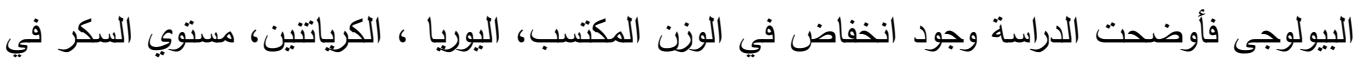
الدم، وزيادة معنوية(P<0.05) في بالمقارنة بالكنترول ، أما نتائج الفحص الهستوباثولوجي (TC, TG, LDL-c, AST, ALT, ALP) فقد أظهرت عدم وجود أبي نأثيرات ضارة لمطحون بذور الرجلة علي كبد أو كلي أو قلب الفئران .

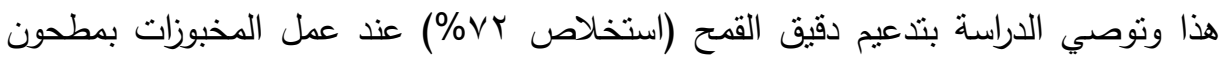

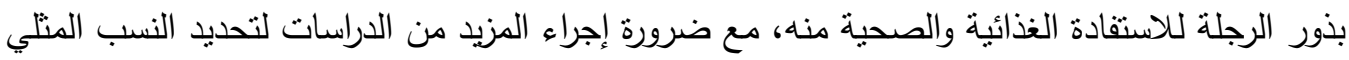

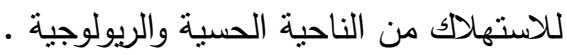
الكلمات المفتاحية:الأعشاب الطبية ، الخواص الحسية ، الخصائص الريولوجية ، التركيب الكيميائي ، دهون الدم ، وظائف الكبد ، وظائف الكلي ، سكر الدم • 